\title{
Does Prenatal Methamphetamine Exposure Induce Sensitization to Drugs in Adulthood?
}

\author{
E. MACÚCHOVÁ ${ }^{1}$, R. ŠLAMBEROVÁ ${ }^{1}$ \\ ${ }^{1}$ Department of Normal, Pathological and Clinical Physiology, Third Faculty of Medicine, Charles \\ University, Prague, Czech Republic
}

Received April 10, 2017

Accepted October 25, 2017

\section{Summary}

Behavioral sensitization is defined as augmented psychomotor activity, which can be observed after drug re-administration following withdrawal of repeated drug exposure. It has been shown that abuse of one drug can lead to increased sensitivity to certain other drugs. This effect of developed general drug sensitivity is called cross-sensitization and has been reported between drugs with similar as well as different mechanisms of action. There is growing evidence that exposure to drugs in utero not only causes birth defects and delays in infant development, but also impairs the neural reward pathways, in the brains of developing offspring, in such a way that it can increase the tendency for drug addiction later in life. This review summarizes the results of preclinical studies that focused on testing behavioral cross-sensitization, after prenatal methamphetamine exposure, to drugs administered in adulthood, with both similar and different mechanisms of action. Traditionally, behavioral sensitization has been examined using the Open field or the Laboras Test to record locomotor activity, and the Conditioned Place Preference and Self-administration test to examine drugseeking behavior. However, it seems that prenatal drug exposure can sensitize animals not only to the locomotor-stimulating and conditioning effects of drugs, but may also be responsible for modified responses to various drug effects.

\section{Key words}

Methamphetamine • Drug abuse • Sensitization • Prenatal drug exposure

\section{Corresponding author}

R. Šlamberová, Department of Normal, Pathological and Clinical Physiology, Third Faculty of Medicine, Charles University, Ke
Karlovu 4, 12000 Prague, Czech Republic. E-mail: romana.slamberova@lf3.cuni.cz

\section{Introduction}

Drug abuse during pregnancy is a serious problem in many countries around the world. Many of the abused drugs can easily cross the placental barrier, and thus women, who take drugs during pregnancy, expose not only themselves but their developing fetus to the harmful effects of the drugs they take. The consequences of prenatal drug exposure are long-lasting and may even continue into adulthood. The question remains whether exposure to a drug of abuse in utero can affect the brain of a developing animal to the point that it leads to a greater predisposition towards drug abuse in adulthood. Several preclinical studies have observed the phenomenon of sensitization, as a progressive and enduring response produced by repeated intermittent prenatal drug administration (Malanga and Kosofsky 2003, Robinson and Berridge 1993, Suzuki et al. 2004).

\section{Behavioral sensitization and cross- sensitization}

In the context of the study of drug addiction, two important terms are defined. The first is tolerance, which refers to the decreased effectiveness of a drug with repeated administration, stated another way; it takes a higher dose of the drug to achieve the same level of response achieved initially. The second term, behavioral or psychomotor sensitization, is defined as a progressive 
and enduring response produced by repeated intermittent drug administration with the same or lower dose (Suzuki et al. 2004). Behavioral sensitization is also referred to as reverse tolerance, behavioral augmentation, or facilitation (Robinson and Becker 1986). It was found that once enhanced drug sensitivity develops, it can persist for extended periods of time (Robinson and Becker 1986). The phenomenon of behavioral sensitization on the effects of various drugs has been observed in several preclinical studies - cocaine (COC) (Estelles et al. 2006), methamphetamine (MA) (Kučerová et al. 2009, Schutová et al. 2010, Šlamberová et al. 2012, Šlamberová et al. 2011, Šlamberová et al. 2011), and morphine (Valjent et al. 2010).

A growing number of studies have shown, that abuse of one drug can lead to increased sensitivity to another drug. Developed general drug sensitivity is called cross-sensitization (Shuster et al. 1977) and has been reported between drugs of similar mechanisms of action such as amphetamine (AMP) and COC (Bonate et al. 1997, Horger et al. 1992, Shuster et al. 1977) and between methylphenidate and AMP (Valvassori et al. 2007). Repeated AMP pre-treatment has been shown to sensitized animals to the locomotor activating effect of COC (Bonate et al. 1997, Shuster et al. 1977). In another study, pre-treatment with AMP enhanced COC self-administration (Ferrario and Robinson 2007). Additionally, cross-sensitization has been demonstrated between drugs with different mechanisms of action, e.g. between opioids and COC (He and Grasing 2004, Leri et al. 2003), and between cannabinoids and opioids (Fattore et al. 2005, Vela et al. 1998).

\section{The neural basis of behavioral sensitization}

Robinson and Berridge (1993) found that with repeated intermittent drug administration, brain regions involved in reward systems become hypersensitive to the specific drug, which results in a pathological drug craving. Despite numerous studies investigating sensitization as a complex process arising from different cellular changes over several brain regions, the neural basis of behavioral sensitization has not been thoroughly characterized. The development of behavioral sensitization after repeated intermittent administration of a psychostimulant is specifically based on changes in the dopaminergic system, i.e. nigrostriatal, mesolimbic, and mesocortical (Robinson and Becker 1986). According to the neural hypothesis, two phases of behavioral sensitization can be defined, (1) the initiation of behavioral sensitization occurs in the ventral tegmental area (VTA) and is defined by a transient sequence of cellular and molecular changes caused by drug administration, and (2) the neuronal events associated with expression of behavioral sensitization are distributed among the interconnected nuclei of motivation circuits and are defined as enduring neural alterations from the initiation process (Kalivas and Stewart 1991, Robinson and Becker 1986).

While an increase in extracellular dopamine (DA) (at the terminals on the nucleus accumbens (NAc)), induced by repeated injections of AMP, can be responsible for behavioral sensitization, increased DA levels in the cell body regions of the VTA have also been found to induce behavioral sensitization (Kalivas and Stewart 1991). Similar to animal models, repeated intermittent administration of AMP has been reported to cause sensitization of DA release in humans, which was still present after one year (Boileau et al. 2006). Although the essential role of dopaminergic receptor type 1 , in behavioral sensitization, has been established in previously published studies using dopaminergic receptor type 1 antagonists, the involvement of dopaminergic receptors type 2 in this process is less clear (Ujike et al. 1989, Vezina and Stewart 1989). Additionally, not only DA but also other neurotransmitters have been shown to be necessary for the expression and induction of behavioral sensitization after psychostimulant treatment (Kalivas and Alesdatter 1993, Wolf 1998). Specifically, increased glutamate transmission in the NAc, striatum, and VTA was reported after repeated intracranial AMP administration (Wolf 1998, Xue et al. 1996). Moreover, after pre-treatment with the non-competitive N-MethylD-aspartic acid (NMDA) antagonist, MK-801, induction of behavioral sensitization was inhibited, indicating that NMDA and $\alpha$-amino-3-hydroxy-5-methyl-4-isoxazolepropionic acid (AMPA) receptors were involved (Stewart and Druhan 1993, Wolf and Jeziorski 1993). It is believed that these receptors are involved in long-term potentiation, which is a key process associated with learning and memory consolidation in the hippocampus (Pu et al. 2002, Šlamberová et al. 2014). Consequently, similar molecular and cellular mechanisms utilized by the brain to form normal memories as well as addictionrelated memories could play a key role in the response to drugs later in life (Šlamberová et al. 2014, Thomas and Malenka 2003).

Nestler (2005) suggested that at least three 
systems play a key role in the development of sensitization. First, as previously mentioned, chronic exposure to any of several commonly abused drugs impairs the VTA-NAc pathway; second, chronic exposure to drugs reduces basal activity in the frontal cortical regions (glutamate projections to the NAC and VTA), which can decrease self-control and increase impulsivity; and third, hyperfunction of corticotropinreleasing factor systems and their connections to the amygdala have been shown to mediate the negative emotional symptoms that occur during drug withdrawal.

\section{Traditional experimental tests used to examine the sensitizing effects of drugs}

There are three models used for testing behavioral and locomotor sensitization (Malanga and Kosofsky 2003). First, there are the Open Field and Laboras tests, which are conducted to test locomotor activity in an unknown environment induced by repeated drug administration, in anthropomorphic terms, a drug-induced euphoria (Malanga and Kosofsky 2003) (Fig. 1A). Then there are tests that measure conditioned drug-paired behavior: a) intravenous self-administration, in which an animal self-administers the drug, (Ferrario and Robinson 2007, Keller et al. 1996, Kučerová et al.
2009), and b) the Conditioned Place Preference test (the CPP test) (Fig. 1B), in which an animal demonstrates preference for an environment that has been associated with a drug (drug-seeking behavior based on conditioning; Malanga and Kosofsky 2003). It was discovered that the expression of behavioral sensitization is strengthened by the association of drug injection with environmental cues. Behavioral sensitization does not manifest when animals were tested in a context where drugs had never been experienced (Anagnostaras and Robinson 1996, Duvauchelle et al. 2000). Different types of animal behavior have previously been reported as a response to repeated psychostimulant administration (e.g. more intense stereotyped behavior including repetitive head movements, increased forward locomotion, rotational behavior, acoustic startle behavior, cage climbing, and others) (Malanga and Kosofsky 2003). There are few studies researching the behavioral expression of sensitization in humans, however, eye-blink responses, and increased vigor and energy ratings were shown to be caused by repeated administration of amphetamines in humans (Strakowski and Sax 1998). Moreover, drug re-administration has been shown to be followed by paranoia and psychosis (Pierce and Kalivas 1997, Robinson and Becker 1986).

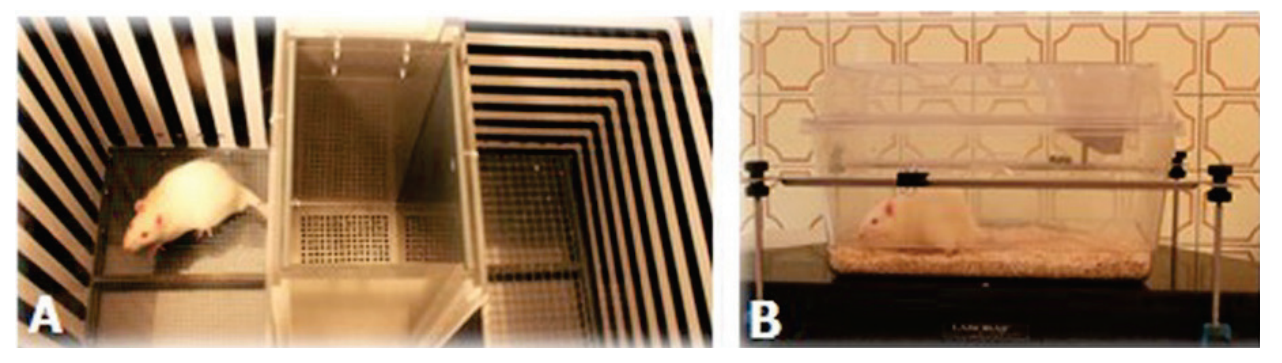

Fig. 1. Apparatuses for two of the tests used to examine behavioral sensitization in rats. (A) The Laboras Test which examines animal activity in an unknown environment. (B) The Conditioned Place Preference Test which examines drug-seeking behavior based on conditioning.

\section{Sensitization induced by prenatal drug exposure}

Not only can sensitization be developed after repeated drug administration in adulthood, but drug exposure in utero can also cause changes in the developing brain of the fetus that lead to increased sensitivity to drugs administered in adulthood (Malanga and Kosofsky 2003). Exposure to drugs of abuse in utero can produce permanent changes in the central nervous system that are distinct from adaptations that occur in mature, homeostatically regulated animals (Stanwood and Levitt 2003).

MA is one of the most frequently abused drugs by female addicts, both in the Czech Republic and worldwide (Marwick 2000, Vavřínková et al. 2001). Moreover, it is the favored drug of pregnant drug-abusing women, because it decreases appetite and food intake and therefore helps women to control their weight, while also increasing energy (Marwick 2000). Therefore, this drug has been of great interest when testing the sensitization developed after prenatal exposure.

Since MA is a lipophilic drug it can easily cross the blood-brain barrier (one of the most resistant barriers of the body), as well as the placental barrier, which is, comparatively, much more permeable (Greenhill 2006, Nordahl et al. 2003). In addition to other drugs, prenatal MA exposure has been shown to have harmful effects on 
both mothers and their offspring. Acuff-Smith et al. (1996) showed that repeated administration of MA to pregnant rats resulted in a higher incidence of delivery failure and maternal death. It also shortened the gestation period, decreased the number of pups per litter, and slowed weight gain during pregnancy (Martin 1975, Martin et al. 1976, Šlamberová et al. 2006). Moreover, prenatal MA exposure has been shown to affect development of postural movements in the pups during the first three weeks of postnatal life (MalinováŠevčíková et al. 2014, Šlamberová et al. 2006, Šlamberová et al. 2007). There are also studies showing that changes in the brain caused by prenatal and neonatal MA exposure can persist into adulthood (Hrebíčková et al. 2014, Hrebičková et al. 2016, Macúchová et al. 2016). Problems in adapting to new environments, long-term cognitive deficits, as well as changes in locomotor activity have also been previously linked to prenatal MA exposure (Schutová et al. 2013, Šlamberová et al. 2005, Weissman and Caldecott-Hazard 1993, Williams et al. 2003).

Various studies have found that prenatal exposure to psychostimulants results in enhanced responsiveness of mesostriatal monoaminergic projections (Rocha et al. 2002, Schneider et al. 2008, Vela et al. 1998). In a study by Bubeníková-Valešová et al. (2009), offspring with prenatal MA exposure had increased brain levels of DA after an acute dose of MA in adulthood, which suggests increased sensitivity to MA long after prenatal exposure. The effect of MA, administered prenatally, has been documented to be dose dependent. A low dose $(2 \mathrm{mg} / \mathrm{kg})$ of MA decreased the expression of DA transporters in the striatum and serotonin (5-HT) transporters in the hippocampus, striatum, and hypothalamus. On the other hand, a high dose $(10 \mathrm{mg} / \mathrm{kg})$ of MA increased the concentration of binding sites for the uptake of DA and 5-HT, suggesting that it stimulates growth of particular axon terminals (Weissman and Caldecott-Hazard 1993).

Methamphetamine at a dose of $5-20 \mathrm{mg} / \mathrm{kg}$ is used in experimental studies because it leads to drug concentrations in the brain that correspond to the amount in the fetuses of drug-dependent mothers (Acuff-Smith et al. 1996, Martin et al. 1976). However, there is still little known about how in utero MA exposure interacts with neurotransmitter systems of the developing brain or how this interaction affects the development of a predisposition for addiction in prenatally exposed offspring.
An increased tendency to abuse drugs in adulthood has been shown in prenatally MA-exposed (Schutová et al. 2010, Šlamberová et al. 2012, Šlamberová et al. 2011), COC-exposed (Keller et al. 1996, Rocha et al. 2002), cannabinoid-exposed (Vela et al. 1998), and morphine-exposed (Gagin et al. 1997) offspring compared to controls. For instance, in a study by Rocha et al. (2002), pregnant mice were given an injection with $\mathrm{COC}$ at two different doses. When their offspring reached adulthood, they were tested in selfadministration experiments. The results showed that intrauterine exposure to $\mathrm{COC}$ contributed the sensitivity to $\mathrm{COC}$ self-administration. In another study by Vela et al. (1998), perinatal delta 9-tetrahydrocannabinol (THC) exposure affected susceptibility to the reinforcing effects of morphine in adulthood, which manifested as increased intravenous morphine self-administration in adult animals.

Šlamberová et al. (2005), introduced a drug injection paradigm for testing behavioral sensitization after prenatal drug exposure. Figure 2 describes a general pattern of induction of behavioral sensitization in prenatally drug exposed animals. When animals reach adulthood, they undergo various test situations with differing drug application (Macúchová et al. 2013, Schutová et al. 2009, Šlamberová et al. 2013, Šlamberová et al. 2012). Several abused drugs, which differ in their mechanism of action, can be used for testing behavioral sensitization. Methamphetamine is an indirect agonist at DA, noradrenaline (NA), and 5-HT receptors. Its main action is to increase the concentration of these three neurotransmitters through reverse transport, as well as uptake inhibition (Sulzer et al. 2005). The accepted opinion is that MA is more addictive and preferred by drug addicts than AMP and, despite structural similarities, MA has been suggested to be a more potent central stimulant with less peripheral activity (Peachey et al. 1977). On the other hand, in a study by Shoblock et al. 2003a and Shoblock et al. 2003b, AMP was shown to be more effective at rising DA levels in the prefrontal cortex than MA. Although, other authors have failed to find any differences in the potencies of AMP and MA in either inducing locomotor activity (Milesi-Halle et al. 2007) or inducing release of DA (Melega et al. 1995). Moreover, MA was shown to have three-fold greater potency than AMP in releasing 5HT. This was first shown in 1960 by Whitby et al. (1960). They found that COC blocks re-uptake of catecholamine, which is now acknowledged to be the 
primary means by which it increases extracellular levels of catecholamine. It has been demonstrated that COC binds with comparable affinity to NA, DA, and 5-HT receptors, while other studies have shown that the serotoninergic system is most affected by COC (Fleckenstein et al. 2000, Rothman and Baumann 2003). Similarly, N-methyl-3,4-methylenedioxyamphetamin (MDMA) interacts with monoamine transporters to reverse the normal direction of transmitter flux and thus cause a non-exocytotic release of 5-HT, DA, and NA (Johnson et al. 1986, Spanos and Yamamoto 1989). MDMA exhibits a greater affinity for 5-HT- compared to DA transporters and recent in vitro experiments have suggested that MDMA is a stronger releaser of 5-HT than DA in the nervous system (Verrico et al. 2007). While morphine directly activates opioid receptors, and THC primarily interacts with cannabinoid receptors, both of these drugs indirectly increase DA and 5-HT release (Johnson and North 1992, Szabo et al. 2002).

This review summarizes the results of studies that focused on testing behavioral cross-sensitization after prenatal MA exposure. The drugs administered in adulthood were divided into two groups: a) MA and drugs that share the same mechanism of action as MA (amphetamine, cocaine, MDMA) (Milesi-Halle et al. 2007, Rothman and Baumann 2003, Spanos and Yamamoto 1989, Sulzer et al. 2005); and b) drugs with a different mechanism of action than MA (morphine and THC) (Johnson and North 1992, Szabo et al. 2002).

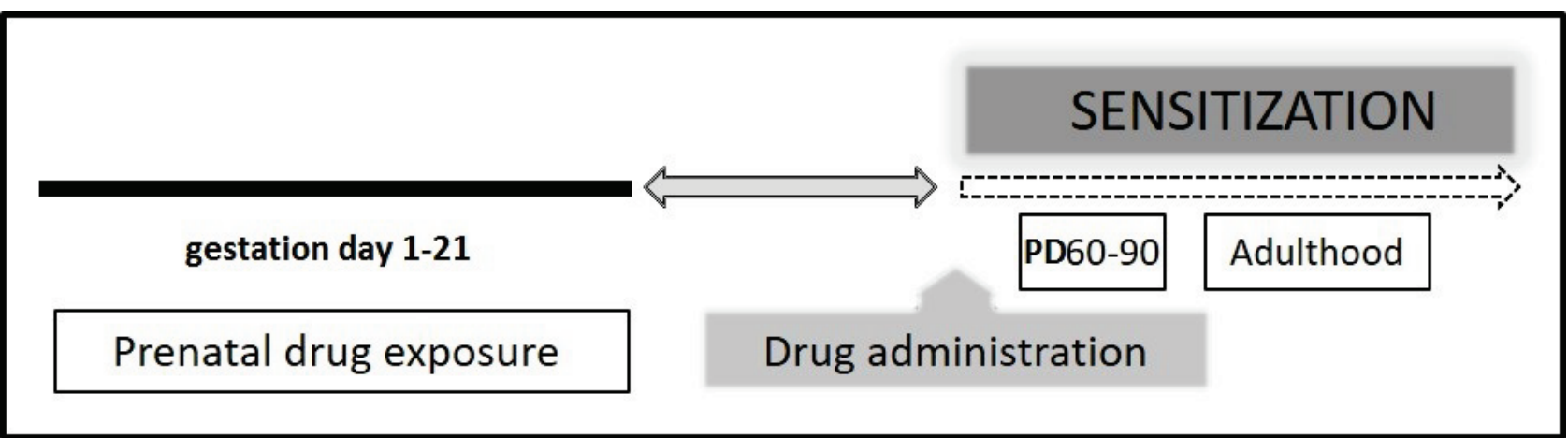

Fig. 2. A drug injection paradigm for testing behavioral sensitization after prenatal drug exposure. Animals are exposed to the prenatal drug during the entire gestation period (from day 1 to day 21). After reaching adulthood postnatal day (PD) 60-90, they experience various test situations with drug administration.

\section{Prenatally drug-induced cross-sensitization to drugs with similar mechanism of action}

The Laboras test revealed that in both male and female rats, prenatal MA exposure induced sensitization, but only to the psychostimulant effects of an acute dose of MA and AMP. Specifically, prenatally MA-exposed males and females compared to saline-exposed animals demonstrated increased locomotor and exploratory activity after acute MA and AMP treatment (Schutová et al. 2013, Šlamberová et al. 2013, Šlamberová et al. 2012). In contrast to results from the Laboras test, data from the CPP test failed to demonstrate any significant increase in active MA- and AMP-seeking behavior induced by prenatal MA exposure (Šlamberová et al. 2011). Based to these results, it has been suggested that although prenatal MA can sensitize animals to the psychostimulant effect of acute MA and AMP, it does not necessarily increase active drug-seeking behavior relative to these drugs. Only females, in the Laboras test, displayed sensitization induced by prenatal MA exposure to COC and MDMA (ک̌lamberová et al. 2013, Šlamberová et al. 2012). Specifically, prenatally MA-exposed females compared to saline-exposed females, demonstrated increased time spent in rearing movements after COC and MDMA treatment. The most likely explanation of this effect, which is found in females but not in males, might be based on sexual dimorphism relative to brain neurotransmitter system development. Vathy et al. (1993) and Vathy et al. (1995) showed that prenatal drug exposure affects the brain of females and males differently (particularly in terms of changes in neurotransmitter levels), suggesting that females might be more sensitive when exposed to other drugs in adulthood. These data regarding sex differences in sensitization are in agreement with studies by Melnick and Dow-Edwards (2001) and Peris et al. (1992), which suggested that sex differences correspond with 
DA activity. More studies need to be conducted to see whether there are also sex differences in DA concentrations, after treatment with different drugs, which could support studies that found sex differences in sensitization.

Šlamberová et al. (2012) found avoidance rather than preference for the chamber associated with COC in animals with prenatal MA exposure, which indicates some kind of tolerance to COC treatment developed after MA exposure in utero. To the best of our knowledge, there are only two studies that also demonstrate tolerance to COC induced by prenatal MA exposure. Peltier et al. (1996) demonstrated that chronic treatment with psychostimulants, such as AMP and MA, produced cross-tolerance to both the discriminative and reinforcing effects of COC. In addition, it has been repeatedly shown that COC affects mostly the serotoninergic system, while MA influences mainly the noradrenergic and dopaminergic systems (Fleckenstein et al. 2000, Rothman and Baumann 2003). This might explain why prenatal MA induces tolerance to the effects of COC (Gygi et al. 1996).

\section{Prenatally drug-induced cross-sensitization to drugs with different mechanisms of action}

As far as the sensitizing effect of prenatal MA exposure relative to adult morphine and THC treatment is concerned, no cross-sensitization has been found either in the CPP test or in the Laboras test. As far as we know, there have been no studies investigating increased sensitivity to morphine after prenatal MA exposure, apart from ours (Šlamberová et al. 2012). Vela et al. (1998) demonstrated that females prenatally exposed to THC during gestation and lactation exhibited an increase in the rate of morphine self-administration. On the other hand, prenatal morphine exposure was not shown to affect morphine self-administration in a study by Riley and Vathy (2006); however, there was an increase in morphine conditioned place preference in a study by Gagin et al. (1997). Interestingly, in the Laboras test, prenatally saline-exposed females demonstrated increased time spent rearing, as well as increased velocity, after THC treatment compared to prenatally MA-exposed females. Such results indicate tolerance to THC, rather than sensitization, induced by prenatal MA exposure in females. Unfortunately, there are no studies examining the long-term effect of prenatal MA on sensitization to $\mathrm{THC}$ in females, which can be compared to these results.

\section{Additional tests used for examining the sensitizing effect of drugs?}

Previous studies have shown that prenatal MA exposure might sensitize animals not only to the locomotor-stimulating effect of drugs administered later in adulthood, but could also be responsible for modified responses to various drug effects. For example, Schutová et al. (2010) found that prenatal MA altered the responsiveness of adult male rats to acute MA administration. Specifically, these results show that prenatally MA-exposed males demonstrated increased anxiolytic behavior in the Elevated Plus-Maze test compared to prenatally saline-exposed males. This indicates that prenatal MA exposure may increase the sensitivity of animals to the anxiogenic behavior induced by acute MA treatment. In the Social Interaction Test, although there were no interactions associated with locomotor activity (non-social behavior), an interesting result was found with regard to social behavior in groups of males treated in adulthood with MA, AMP, and MDMA. Specifically, prenatally MA-exposed males, when given an acute exposure to MA, AMP, and MDMA, showed decreased time spent in social interactions compared to saline-exposed animals treated in adulthood with the same drugs. It appears, that prenatal MA exposure sensitized the animals, resulting in reduced social behavior after receiving the same drugs as adults (Šlamberová et al. 2015).

Although, prenatal exposure to MA at a dose of $5 \mathrm{mg} / \mathrm{kg}$ does not lead to changes that persist until adulthood, in terms of worsened spatial learning, it does seem to cause some alterations, which in turn lead to different responses to the drug when administered in adulthood (Hrubá et al. 2010, Macúchová et al. 2013, Macúchová et al. 2014, Schutová et al. 2009). Alterations in swimming strategies, defined by using less spatial strategies of swimming and more scanning and thigmotaxis, can be seen after chronic treatment with MA, AMP (Macúchová et al. 2013, Macúchová et al. 2014, Schutová et al. 2009), as well as other drugs (COC, MDMA, THC, morphine (Macúchová et al. 2017).

\section{Conclusions}

To summarize, this review gives new insight into the problem of induced sensitization after prenatal MA exposure. Despite numerous studies investigating sensitization as a complex process arising from different 
cellular changes in many regions of the brain, its neural basis is still not fully understood. MA is one of the more accessible drugs in the Czech Republic as well as worldwide, and in many cases, the first drug of choice for many drug-addicted pregnant women. Therefore, the question of whether children born to mothers, who abused MA during pregnancy, have an increased risk of substance abuse or other addictive behaviors after they grow up and enter adulthood is of critical importance. The question is particularly pertinent since events that stress neural development in prenatal life, can in many cases, lead to changes that persist until adulthood. This can consequently impair healthy development and future social inclusion of children as they mature. Since clinical studies are difficult to perform, developing a testable hypothesis through preclinical research can potentially increase the likelihood of finding a neurobiological basis for the increased predisposition for addiction in prenatally MA-exposed offspring. It has been shown that we cannot simply conclude that prenatal MA exposure leads to an increased sensitivity to abused drugs, and thus leads to the development of drug addiction.

The offspring of rats treated with MA during the entire gestational period can be sensitized to the application of other drugs in adulthood. Specifically, it seems that animals, after MA exposure in utero, demonstrate some kind of locomotor augmentation when exposed to psychostimulants (e.g. cocaine, amphetamine, or MDMA) later in adulthood. However, the increased locomotor reaction depends on the mechanism by which the drug acts. In addition, other test situations have revealed interactions between prenatal dug exposure and drug administration in adulthood. These are interesting findings that highlight the fact that the basis for sensitization may go beyond the classical concept of augmented locomotor reactions after drug treatment. Moreover, it seems that exposure to MA during the gestational period does not predispose offspring to an increased need for MA later in life. In anthropomorphic language, children of mothers who used MA during pregnancy might have an increased reaction to other drugs when they encounter them later in life, and this situation (i.e. the increased response) by itself might intensify their interest in using drugs.

\section{Conflict of Interest}

There is no conflict of interest.

\section{Acknowledgements}

This study was supported by research program Progres Q35 from Charles University. The authors express their appreciation to Thomas Ownsby Secrest, M.Sc. for critical reading and editing of the manuscript.

\section{Abbreviations}

5-HT - serotonin, AMP - amphetamine, AMPA $\alpha$-amino-3-hydroxy-5-methyl-4-isoxazolepropionic acid, COC - cocaine, CPP - the Conditioned Place Preference test, DA - dopamine, MA - methamphetamine, MDMA N-methyl-3,4-methylenedioxyamphetamine, NA noradrenaline, NAc - the nucleus accumbens, NMDA N-methyl-D-aspartate receptor, PD - postnatal day, THC - delta9-tetrahydrocannabinol, VTA - the ventral tegmental area.

\section{References}

ACUFF-SMITH KD, SCHILLING MA, FISHER JE, VORHEES CV: Stage-specific effects of prenatal d-methamphetamine exposure on behavioral and eye development in rats. Neurotoxicol Teratol 18: 199-215, 1996.

ANAGNOSTARAS SG, ROBINSON TE: Sensitization to the psychomotor stimulant effects of amphetamine: modulation by associative learning. Behav Neurosci 110: 1397-414, 1996.

BOILEAU I, DAGHER A, LEYTON M, GUNN RN, BAKER GB, DIKSIC M, BENKELFAT C: Modeling sensitization to stimulants in humans: an [11C]raclopride/positron emission tomography study in healthy men. Arch Gen Psychiatry 63: 1386-1395, 2006.

BONATE PL, SWANN A, SILVERMAN PB: Behavioral sensitization to cocaine in the absence of altered brain cocaine levels. Pharmacol Biochem Behav 57: 665-669, 1997.

BUBENIKOVÁ-VALEŠOVÁ V, KAČER P, SYSLOVÁ K, RAMBOUSEK L, JANOVSKÝ M, SCHUTOVÁ B, HRUBÁ L, ŠLAMBEROVÁ R: Prenatal methamphetamine exposure affects the mesolimbic dopaminergic system and behavior in adult offspring. Int J Dev Neurosci 27: 525-530, 2009. 
DUVAUCHELlE CL, IKEGAMI A, CASTANEDA E: Conditioned increases in behavioral activity and accumbens dopamine levels produced by intravenous cocaine. Behav Neurosci 114: 1156-1166, 2000.

ESTELLES J, RODRIGUEZ-ARIAS M, MALDONADO C, AGUILAR MA, MINARRO J: Gestational exposure to cocaine alters cocaine reward. Behav Pharmacol 17: 509-515, 2006.

FATTORE L, DEIANA S, SPANO SM, COSSU G, FADDA P, SCHERMA M, FRATTA W: Endocannabinoid system and opioid addiction: behavioural aspects. Pharmacol Biochem Behav 81: 343-359, 2005.

FERRARIO CR, ROBINSON TE: Amphetamine pretreatment accelerates the subsequent escalation of cocaine self-administration behavior. Eur Neuropsychopharmacol 17: 352-357, 2007.

FLECKENSTEIN AE, GIBB JW, HANSON GR: Differential effects of stimulants on monoaminergic transporters: pharmacological consequences and implications for neurotoxicity. Eur J Pharmacol 406: 1-13, 2000.

GAGIN R, KOOK N, COHEN E, SHAVIT Y: Prenatal morphine enhances morphine-conditioned place preference in adult rats. Pharmacol Biochem Behav 58: 525-528, 1997.

GREENHILL LL: The science of stimulant abuse. Pediatr Ann 35: 552-556, 2006.

GYGI MP, GYGI SP, JOHNSON M, WILKINS DG, GIBB JW, HANSON GR: Mechanisms for tolerance to methamphetamine effects. Neuropharmacology 35: 751-757, 1996.

HE S, GRASING K: Chronic opiate treatment enhances both cocaine-reinforced and cocaine-seeking behaviors following opiate withdrawal. Drug Alcohol Depend 75: 215-221, 2004.

HORGER BA, GILES MK, SCHENK S: Preexposure to amphetamine and nicotine predisposes rats to self-administer a low dose of cocaine. Psychopharmacology (Berl) 107: 271-276, 1992.

HREBÍČKOVÁ I, MALINOVÁ-ŠEVČÍKOVÁ M, MACÚCHOVÁ E, NOHEJLOVÁ K, ŠLAMBEROVÁ R: Exposure to methamphetamine during first and second half of prenatal period and its consequences on cognition after long-term application in adulthood. Physiol Res 63 (Suppl 4): S535-S545, 2014.

HREBÍČKOVÁ I, ŠEVČÍKOVÁ M, NOHEJLOVÁ K, ŠLAMBEROVÁ R: Does effect from developmental methamphetamine exposure on spatial learning and memory depend on stage of neuroontogeny? Physiol Res 65 (Suppl 5): S577-S589, 2016.

HRUBÁ L, SCHUTOVÁ B, POMETLOVÁ M, ROKYTA R, ŠLAMBEROVÁ R: Effect of methamphetamine exposure and cross-fostering on cognitive function in adult male rats. Behav Brain Res 208: 63-71, 2010.

JOHNSON MP, HOFFMAN AJ, NICHOLS DE: Effects of the enantiomers of MDA, MDMA and related analogues on $[3 \mathrm{H}]$ serotonin and $[3 \mathrm{H}]$ dopamine release from superfused rat brain slices. Eur J Pharmacol 132: 269-276, 1986.

JOHNSON SW, NORTH RA: Opioids excite dopamine neurons by hyperpolarization of local interneurons. $J$ Neurosci 12: 483-488, 1992.

KALIVAS PW, ALESDATTER JE: Involvement of N-methyl-D-aspartate receptor stimulation in the ventral tegmental area and amygdala in behavioral sensitization to cocaine. J Pharmacol Exp Ther 267: 486-495, 1993.

KALIVAS PW, STEWART J: Dopamine transmission in the initiation and expression of drug- and stress-induced sensitization of motor activity. Brain Res Brain Res Rev 16: 223-244, 1991.

KELLER RW JR, LEFEVRE R, RAUCCI J, CARLSON JN, GLICK SD: Enhanced cocaine self-administration in adult rats prenatally exposed to cocaine. Neurosci Lett 205: 153-156, 1996.

KUČEROVÁ J, VRŠKOVÁ D, ŠULCOVÁ A: Impact of repeated methamphetamine pretreatment on intravenous self-administration of the drug in males and estrogenized or non- estrogenized ovariectomized female rats. Neuro Endocrinol Lett 30: 663-670, 2009.

LERI F, FLORES J, RAJABI H, STEWART J: Effects of cocaine in rats exposed to heroin. Neuropsychopharmacology 28: 2102-2116, 2003.

MACÚCHOVÁ E, NOHEJLOVÁ-DEYKUN K, ŠLAMBEROVÁ R: Effect of methamphetamine on cognitive functions of adult female rats prenatally exposed to the same drug. Physiol Res 62 (Suppl 1): S89-S98, 2013.

MACÚCHOVÁ E, NOHEJLOVÁ K, ŠEVČÍKOVÁ M, HREBÍČKOVÁ I, ŠLAMBEROVÁ R: Sex differences in strategies of spatial learning in prenatally-exposed rats treated with various drugs in adulthood. Behav Brain Res 327: 83-93, 2017.

MACÚCHOVÁ E, NOHEJLOVÁ K, ŠLAMBEROVÁ R: Gender differences in the effect of adult amphetamine on cognitive functions of rats prenatally exposed to methamphetamine. Behav Brain Res 270: 8-17, 2014. 
MACÚCHOVÁ E, ŠEVČÍKOVÁ M, HREBÍČKOVÁ I, NOHEJLOVÁ K, ŠLAMBEROVÁ R: How various drugs affect anxiety-related behavior in male and female rats prenatally exposed to methamphetamine. Int $J$ Dev Neurosci 51: 1-11, 2016.

MALANGA CJ, KOSOFSKY BE: Does drug abuse beget drug abuse? Behavioral analysis of addiction liability in animal models of prenatal drug exposure. Brain Res Dev Brain Res 147: 47-57, 2003.

MALINOVÁ-ŠEVČÍKOVÁ M, HREBÍČKOVÁ I, MACÚCHOVÁ E, NOVÁ E, POMETLOVA M, ŠLAMBEROVÁ $R$ : Differences in maternal behavior and development of their pups depend on the time of methamphetamine exposure during gestation period. Physiol Res 63 (Suppl 4): S559-S572, 2014.

MARTIN JC: Effects on offspring of chronic maternal methamphetamine exposure. Dev Psychobiol 8: 397-404, 1975.

MARTIN JC, MARTIN DC, RADOW B, SIGMAN G: Growth, development and activity in rat offspring following maternal drug exposure. Exp Aging Res 2: 235-251, 1976.

MARWICK C: NIDA seeking data on effect of fetal exposure to methamphetamine. JAMA 283: 2225-2226, 2000.

MELEGA WP, WILLIAMS AE, SCHMITZ DA, DISTEFANO EW, CHO AK: Pharmacokinetic and pharmacodynamic analysis of the actions of D-amphetamine and D-methamphetamine on the dopamine terminal. J Pharmacol Exp Ther 274: 90-96, 1995.

MELNICK SM, DOW-EDWARDS DL: Differential behavioral responses to chronic amphetamine in adult male and female rats exposed to postnatal cocaine treatment. Pharmacol Biochem Behav 69: 219-24, 2001.

MILESI-HALLE A, MCMILLAN DE, LAURENZANA EM, BYRNES-BLAKE KA, OWENS SM: Sex differences in $(+)$-amphetamine- and (+)-methamphetamine-induced behavioral response in male and female Sprague-Dawley rats. Pharmacol Biochem Behav 86: 140-149, 2007.

NESTLER EJ: Is there a common molecular pathway for addiction? Nat Neurosci 8: 1445-1449, 2005.

NORDAHL TE, SALO R, LEAMON M: Neuropsychological effects of chronic methamphetamine use on neurotransmitters and cognition: a review. J Neuropsychiatry Clin Neurosci 15: 317-325, 2003.

PEACHEY JE, ROGERS B, BRIEN JF: A comparative study of the behavioural responses induced by chronic administration of methamphetamine and amphetamine in mice. Psychopharmacology (Berl) 51: 137-140, 1977.

PELTIER RL, LI DH, LYTLE D, TAYLOR CM, EMMETT-OGLESBY MW: Chronic d-amphetamine or methamphetamine produces cross-tolerance to the discriminative and reinforcing stimulus effects of cocaine. J Pharmacol Exp Ther 277: 212-218, 1996.

PERIS J, COLEMAN-HARDEE M, MILLARD WJ: Cocaine in utero enhances the behavioral response to cocaine in adult rats. Pharmacol Biochem Behav 42: 509-515, 1992.

PIERCE RC, KALIVAS PW: A circuitry model of the expression of behavioral sensitization to amphetamine-like psychostimulants. Brain Res Brain Res Rev 25: 192-216, 1997.

PU L, BAO GB, XU NJ, MA L, PEI G: Hippocampal long-term potentiation is reduced by chronic opiate treatment and can be restored by re-exposure to opiates. J Neurosci 22: 1914-1921, 2002.

RILEY MA, VATHY I: Mid- to late gestational morphine exposure does not alter the rewarding properties of morphine in adult male rats. Neuropharmacology 51: 295-304, 2006.

ROBINSON TE, BECKER JB: Enduring changes in brain and behavior produced by chronic amphetamine administration: a review and evaluation of animal models of amphetamine psychosis. Brain Res 396: 157-198, 1986.

ROBINSON TE, BERRIDGE KC: The neural basis of drug craving: an incentive-sensitization theory of addiction. Brain Res Brain Res Rev 18: 247-291, 1993.

ROCHA BA, MEAD AN, KOSOFSKY BE: Increased vulnerability to self-administer cocaine in mice prenatally exposed to cocaine. Psychopharmacology (Berl) 163: 221-229, 2002.

ROTHMAN RB, BAUMANN MH: Monoamine transporters and psychostimulant drugs. Eur J Pharmacol 479: 23-40, 2003.

SHOBLOCK JR, MAISONNEUVE IM, GLICK SD: Differences between d-methamphetamine and d-amphetamine in rats: working memory, tolerance, and extinction. Psychopharmacology (Berl) 170: 150-156, 2003 a.

SHOBLOCK JR, SULLIVAN EB, MAISONNEUVE IM, GLICK SD: Neurochemical and behavioral differences between d-methamphetamine and d-amphetamine in rats. Psychopharmacology (Berl) 165: 359-369, 2003b. 
SHUSTER L, YU G, BATES A: Sensitization to cocaine stimulation in mice. Psychopharmacology (Berl) 52: 185-190, 1977.

SCHNEIDER M, SCHOMIG E, LEWEKE FM: Acute and chronic cannabinoid treatment differentially affects recognition memory and social behavior in pubertal and adult rats. Addict Biol 13: 345-357, 2008.

SCHUTOVÁ B, HRUBÁ L, POMETLOVÁ M, DEYKUN K, ŠLAMBEROVÁ R: Cognitive functions and drug sensitivity in adult male rats prenatally exposed to methamphetamine. Physiol Res 58: 741-750, 2009.

SCHUTOVÁ B, HRUBÁ L, POMETLOVÁ $M$, ROKYTA $R$, ŠLAMBEROVÁ $R$ : Responsiveness to methamphetamine in adulthood is altered by prenatal exposure in rats. Physiol Behav 99: 381-387, 2010.

SCHUTOVÁ B, HRUBÁ L, ROKYTA R, ŠLAMBEROVÁ R: Gender differences in behavioral changes elicited by prenatal methamphetamine exposure and application of the same drug in adulthood. Dev Psychobiol 55: 232-242, 2013.

ŠLAMBEROVÁ R, MACÚCHOVÁ E, NOHEJLOVÁ-DEYKUN K, SCHUTOVÁ B, HRUBÁ L, ROKYTA R: Gender differences in the effect of prenatal methamphetamine exposure and challenge dose of other drugs on behavior of adult rats. Physiol Res 62 (Suppl 1): S99-S108, 2013.

ŠLAMBEROVÁ R, POMETLOVÁ M, CHAROUSOVÁ P: Postnatal development of rat pups is altered by prenatal methamphetamine exposure. Prog Neuropsychopharmacol Biol Psychiatry 30: 82-88, 2006.

ŠLAMBEROVÁ R, POMETLOVÁ M, MACÚCHOVÁ E, NOHEJLOVÁ K, STUCHLÍK A, VALEŠ K: Do the effects of prenatal exposure and acute treatment of methamphetamine on anxiety vary depending on the animal model used? Behav Brain Res 292: 361-369, 2015.

ŠLAMBEROVÁ R, POMETLOVÁ M, ROKYTA R: Effect of methamphetamine exposure during prenatal and preweaning periods lasts for generations in rats. Dev Psychobiol 49: 312-322, 2007.

ŠLAMBEROVÁ R, POMETLOVÁ M, SCHUTOVÁ B, HRUBÁ L, MACÚCHOVA E, NOVÁ E, ROKYTA R: Do prenatally methamphetamine-exposed adult male rats display general predisposition to drug abuse in the conditioned place preference test? Physiol Res 61 (Suppl 2): S129-S138, 2012.

ŠLAMBEROVÁ R, POMETLOVÁ M, SYLLABOVÁ L, MANCUŠKOVÁ M: Learning in the Place navigation task, not the New-learning task, is altered by prenatal methamphetamine exposure. Brain Res Dev Brain Res 157: 217-219, 2005.

ŠLAMBEROVÁ R, SCHUTOVÁ B, HRUBÁ L, POMETLOVÁ M: Does prenatal methamphetamine exposure affect the drug-seeking behavior of adult male rats? Behav Brain Res 224: 80-86, 2011.

ŠLAMBEROVÁ R, VRAJOVÁ M, SCHUTOVÁ B, MERTLOVÁ M, MACÚCHOVÁ E, NOHEJLOVÁ K, HRUBÁ L, PUSKARČÍKOVÁ J, BUBENÍKOVÁ-VALEŠOVÁ V, YAMAMOTOVÁ A: Prenatal methamphetamine exposure induces long-lasting alterations in memory and development of NMDA receptors in the hippocampus. Physiol Res 63 (Suppl 4): S547-S558, 2014.

ŠLAMBEROVÁ R, YAMAMOTOVÁ A, SCHUTOVÁ B, HRUBÁ L, POMETLOVÁ M: Impact of prenatal methamphetamine exposure on the sensitivity to the same drug in adult male rats. Prague Med Rep 112: 102-114, 2011.

SPANOS LJ, YAMAMOTO BK: Acute and subchronic effects of methylenedioxymethamphetamine [(+/-)MDMA] on locomotion and serotonin syndrome behavior in the rat. Pharmacol Biochem Behav 32: 835-840, 1989.

STANWOOD GD, LEVITT P: Repeated i.v. cocaine exposure produces long-lasting behavioral sensitization in pregnant adults, but behavioral tolerance in their offspring. Neuroscience 122: 579-583, 2003.

STEWART J, DRUHAN JP: Development of both conditioning and sensitization of the behavioral activating effects of amphetamine is blocked by the non-competitive NMDA receptor antagonist, MK-801. Psychopharmacology (Berl) 110: 125-132, 1993.

STRAKOWSKI SM, SAX KW: Progressive behavioral response to repeated d-amphetamine challenge: further evidence for sensitization in humans. Biol Psychiatry 44: 1171-1177, 1998.

SULZER D, SONDERS MS, POULSEN NW, GALLI A: Mechanisms of neurotransmitter release by amphetamines: a review. Prog Neurobiol 75: 406-433, 2005.

SUZUKI T, FUKUOKA Y, MORI T, MIYATAKE M, NARITA M: Behavioral sensitization to the discriminative stimulus effects of methamphetamine in rats. Eur J Pharmacol 498: 157-161, 2004. 
SZABO B, SIEMES S, WALLMICHRATH I: Inhibition of GABAergic neurotransmission in the ventral tegmental area by cannabinoids. Eur J Neurosci 15: 2057-2061, 2002.

THOMAS MJ, MALENKA RC: Synaptic plasticity in the mesolimbic dopamine system. Philos Trans $R$ Soc Lond B Biol Sci 358: 815-819, 2003.

UJIKE H, ONOUE T, AKIYAMA K, HAMAMURA T, OTSUKI S: Effects of selective D-1 and D-2 dopamine antagonists on development of methamphetamine-induced behavioral sensitization. Psychopharmacology (Berl) 98: 89-92, 1989.

VALJENT E, BERTRAN-GONZALEZ J, AUBIER B, GREENGARD P, HERVE D, GIRAULT JA: Mechanisms of locomotor sensitization to drugs of abuse in a two-injection protocol. Neuropsychopharmacology 35: 401-415, 2010.

VALVASSORI SS, FREY BN, MARTINS MR, REUS GZ, SCHIMIDTZ F, INACIO CG, KAPCZINSKI F, QUEVEDO J: Sensitization and cross-sensitization after chronic treatment with methylphenidate in adolescent Wistar rats. Behav Pharmacol 18: 205-212, 2007.

VATHY I, KATAY L, MINI KN: Sexually dimorphic effects of prenatal cocaine on adult sexual behavior and brain catecholamines in rats. Brain Res Dev Brain Res 73: 115-122, 1993.

VATHY I, RIMANOCZY A, EATON RC, KATAY L: Sex dimorphic alterations in postnatal brain catecholamines after gestational morphine. Brain Res Bull 36: 185-193, 1995.

VAVŘÍNKOVÁ B, BINDER T, ŽIVNÝ J: Characteristics of a population of drug dependent pregnant women in the Czech Republic. (In Czech) Ceska Gynekol 66: 285-291, 2001.

VELA G, MARTIN S, GARCIA-GIL L, CRESPO JA, RUIZ-GAYO M, FERNANDEZ-RUIZ JJ, GARCIA-LECUMBERRI C, PELAPRAT D, FUENTES JA, RAMOS JA, AMBROSIO E: Maternal exposure to delta9-tetrahydrocannabinol facilitates morphine self-administration behavior and changes regional binding to central mu opioid receptors in adult offspring female rats. Brain Res 807: 101-109, 1998.

VERRICO CD, MILLER GM, MADRAS BK: MDMA (Ecstasy) and human dopamine, norepinephrine, and serotonin transporters: implications for MDMA-induced neurotoxicity and treatment. Psychopharmacology (Berl) 189: 489-503, 2007.

VEZINA P, STEWART J: The effect of dopamine receptor blockade on the development of sensitization to the locomotor activating effects of amphetamine and morphine. Brain Res 499: 108-120, 1989.

WEISSMAN AD, CALDECOTT-HAZARD S: In utero methamphetamine effects: I. Behavior and monoamine uptake sites in adult offspring. Synapse 13: 241-250, 1993.

WHITBY LG, HERTTING G, AXELROD J: Effect of cocaine on the disposition of noradrenaline labelled with tritium. Nature 187: 604-605, 1960.

WILLIAMS MT, BLANKENMEYER TL, SCHAEFER TL, BROWN CA, GUDELSKY GA, VORHEES CV: Long-term effects of neonatal methamphetamine exposure in rats on spatial learning in the Barnes maze and on cliff avoidance, corticosterone release, and neurotoxicity in adulthood. Brain Res Dev Brain Res 147: 163-175, 2003.

WOLF ME: The role of excitatory amino acids in behavioral sensitization to psychomotor stimulants. Prog Neurobiol 54: 679-720, 1998.

WOLF ME, JEZIORSKI M: Coadministration of MK-801 with amphetamine, cocaine or morphine prevents rather than transiently masks the development of behavioral sensitization. Brain Res 613: 291-294, 1993.

XUE CJ, NG JP, LI Y, WOLF ME: Acute and repeated systemic amphetamine administration: effects on extracellular glutamate, aspartate, and serine levels in rat ventral tegmental area and nucleus accumbens. $J$ Neurochem 67 : 352-363, 1996. 